\title{
THE DEGREE OF EFFECTIVENESS OF DISTANCE LEARNING IN LIGHT OF THE OUTBREAK OF THE CORONA VIRUS FROM THE POINT OF VIEW OF STUDENTS IN HIGHER EDUCATION INSTITUTIONS IN BEERSHEBA
}

\author{
Hatem AZBARGA ${ }^{1}$
}

\section{Istanbul / Türkiye \\ p. $268-285$}

Received: $26 / 11 / 2021$

Accepted: $13 / 12 / 2021$

Published: 01/01/2022

This article has been scanned k iThenticat No plagiarism detected

\begin{abstract}
:
The study aims to identify the degree of effectiveness of distance learning in light of Covid-19 outbreak from the point of view of students in higher education institutions in Beersheba. In this study, the researcher used the descriptive approach through a questionnaire that was given to (150) students in higher education institutions in Beersheba. The students were chosen randomly, and the validity of the study tool was verified by presenting it to a group of arbitrators, and its stability was verified, as the value of Cronbach's alpha was (94.4\%), which has a high degree of stability, and appropriate statistical methods were used for: Reaching the results The results were as follows:

1. The degree of effectiveness of distance learning in light of the outbreak of the Corona virus from the point of view of students in higher education institutions in Beersheba region came to a medium degree.

2. The degree of continuity of distance learning in light of the outbreak of the Corona virus from the point of view of students in higher education institutions in Beersheba region came to a medium degree.

3. The degree of e-learning obstacles from the point of view of students in higher education institutions in Beersheba region came to a medium degree.

4. The degree of interaction of faculty members with distance education in light of the Corona crisis from the point of view of students in higher education institutions in Beersheba region came to a medium degree.

5. The degree of students' interaction with distance learning in light of e-learning from the point of view of students in higher education institutions in Beersheba region came to a high degree.

6. There are statistically significant differences in the responses of the study sample members towards the degree of effectiveness of distance learning in light of the outbreak of the Corona virus from the point of view of students in higher education institutions in Beersheba region due to the gender variable, and the differences were in favor of females versus males.

7. There are differences in the average responses of the sample members about the degree of effectiveness of distance learning in
\end{abstract}

http: //dx.doi.org/10.47832/2717-8293.15.20

1 iD) Dr. , Palestine, hatemm10@gmail.com, https://orcid.org/0000-0003-3520-4380 
light of the outbreak of the Corona virus from the point of view of students in higher education institutions in Beersheba region due to the variable of the teaching stage in the college in favor of those studying a teaching certificate versus those studying a first and a second title.

8. There are no differences in the average responses of the sample members about the degree of effectiveness of distance learning in light of the outbreak of the Corona virus from the point of view of students in higher education institutions in Beersheba region due to the variable of the year of study in the college.

Key words: The Effectiveness of Distance Learning, The Corona Virus, Higher Education Institutions.

\section{درجة فاعلية التعلم عن بعد في ظل تفشّي فيروس الكورونا من وجهة نظر طلبة

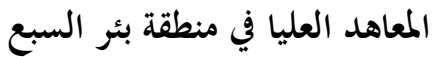

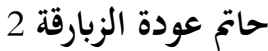

\section{الملخص:}

هدفت لدراسة إلى التعرف على درجة فاعلية التعلم عن بعد في ظل تفشّي فيروس الكورونا من وجهة نظر طلبة

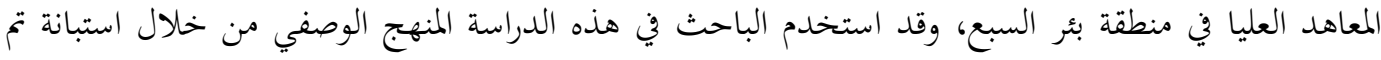

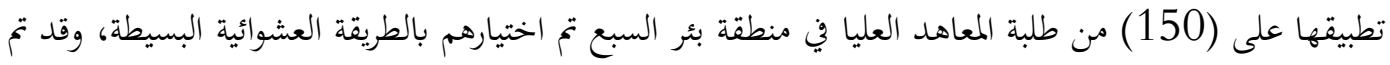

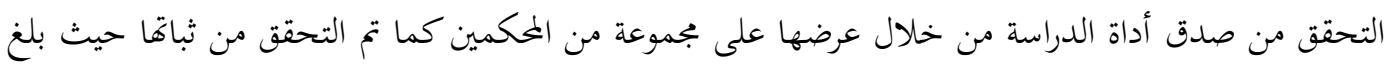

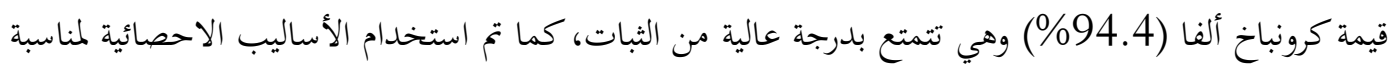
من أجل التوصل إلى النتائج وكانت النتائج على النحو الآتي:

1. أن درجة فاعلية التعلم عن بعد في ظل تفشّي فيروس الكورونا من وجهة نظر طلبة المعاهد العليا في منطقة بئر

$$
\text { السبع جاءت بدرجة متوسطة }
$$

2. أن درجة استمرارية التعلم عن بعد في ظل تفشّي فيروس كورونا من وجهة نظر طلبة المعاهد العليا في منطقة

$$
\text { بئر السبع جاءت بدرجة متوسطة }
$$

3. أن درجة معيقات التعليم الإلكتروني من وجهة نظر طلبة المعاهد العليا في منطقة بئر السبع جاءت بدرجة بلدة

4. أن درجة تفاعل أعضاء هيئة التدريس مع التعليم عن بعد في ظل ازمة كورونا من وجهة نظر طلبة المعاهد

$$
\text { العليا في منطقة بئر السبع جاءت بدرجة متوسطة }
$$

5. أن درجة تفاعل الطلبة مع التعلم عن بعد في ظل التعليم الإلكتروين من وجهة نظر طلبة المعاهد العليا في

$$
\text { منطقة بئر السبع جاءت بدرجة مرتفعة }
$$


6. توجد فروق ذات دلالة إحصائيّة في استجابات أفراد عيّنة الدّراسة نحو درجة فاعلية التعلم عن بعد في ظل

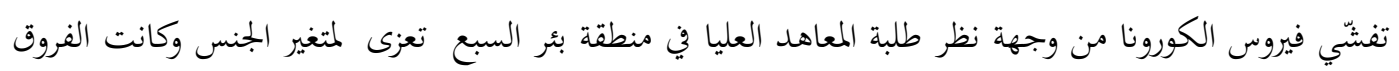
لصالح الإناث مقابل الذكور 7. توجد فروق في متوسطات استجابات أفراد العينة حول درجة فاعلية التعلم عن بعد في ظل تفشّي فيروس

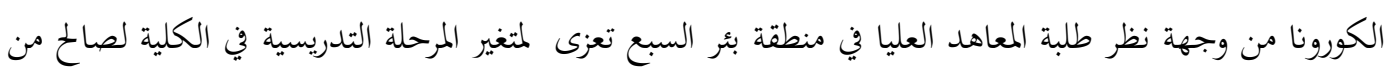
يدرسون شهادة التدريس مقابل من يدرسون لقب أول ولقب ثاني

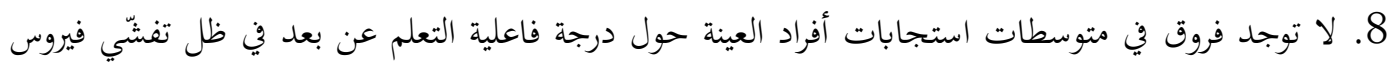
الكورونا من وجهة نظر طلبة المعاهد العليا في منطقة بئر السبع تعزى لمتغير السنة الدراسة في الكلية. الكلمات المفتاحية: فاعلية التعلم عن بعد، فيروس الكورونا، المعاهد العليا. 
ما درجة فاعلية التعلم عن بعد في ظل تفشّي فيروس الكورونا من وجهة نظر طلبة المعاهد العليا في منطقة بئر السبع؟

أهمية البحث:

تظهر أهمية الدراسة من خلال إظهار أهمية التعليم عن بعد في ظل أزمة كورنا، كما أن التعليم عن بعد من أهم الوسائل

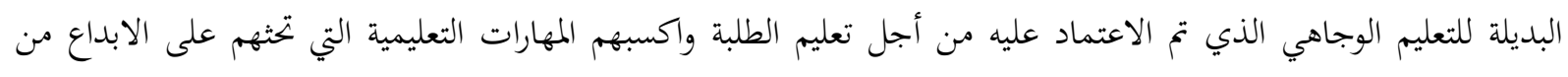

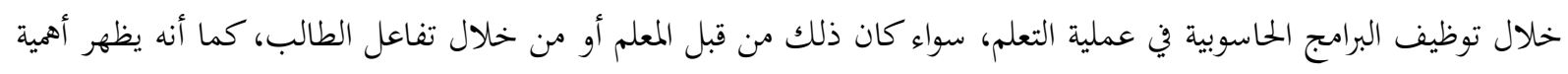

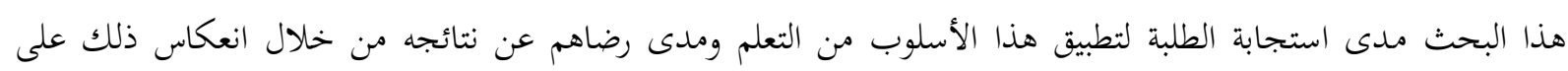

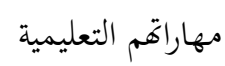

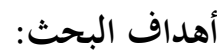

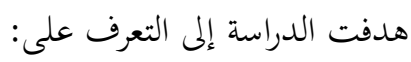

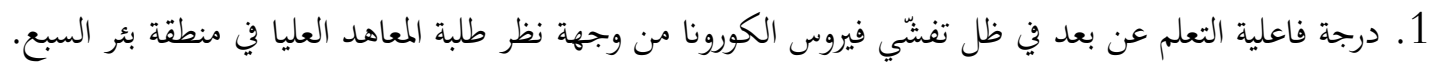

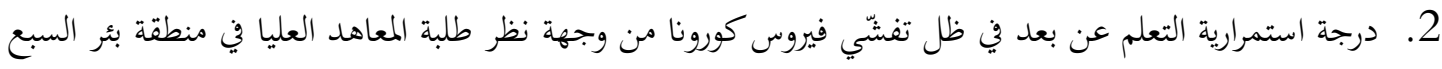

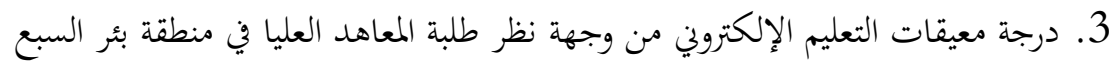
4. درجة تفاعل أعضاء هيئة التدريس مع التعليم عن بعد في ظل ازمة كورونا من وجهة نظر طلبة المبات المعاهد العليا في منطقة بئر

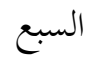

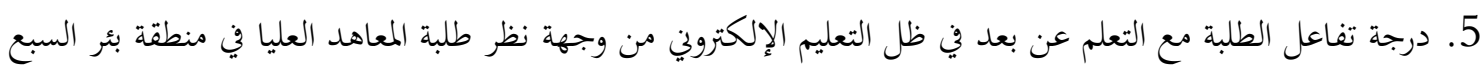

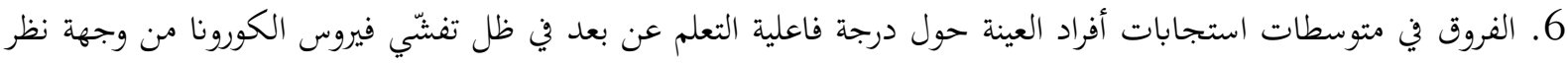

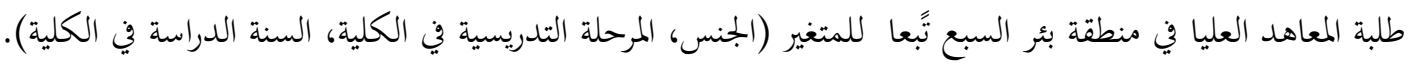

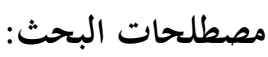
- التعليم عن بعد: هو ذلك النوع من التعليم الذي يعتمد على استخدام الوسائط الإلكترونية في تحقيق الأهداف التعليمية

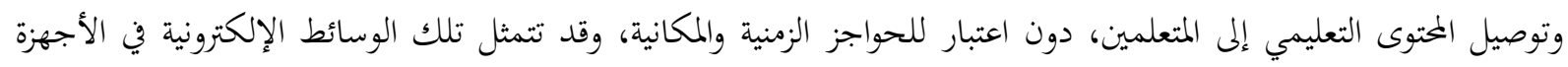

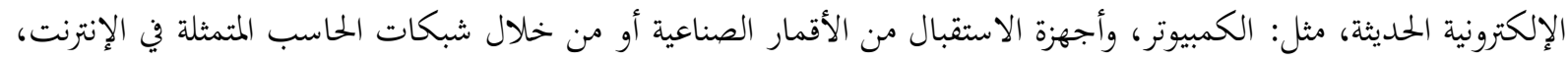

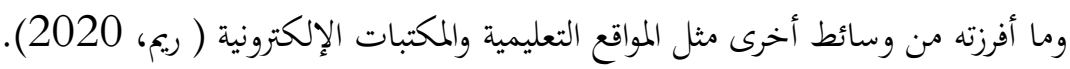

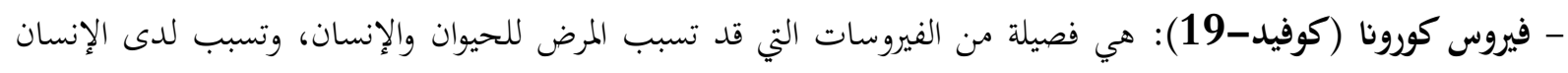

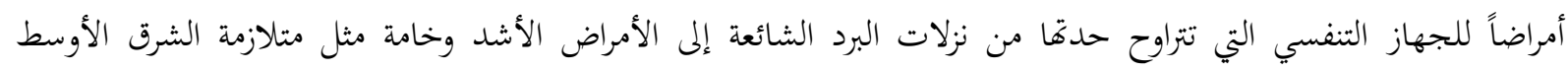

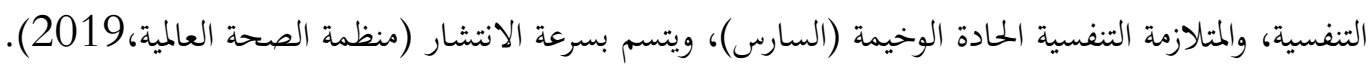

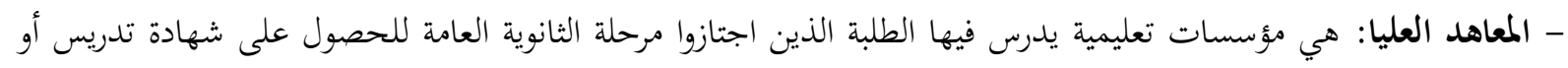
لقب أول أو لقب ثاني. 


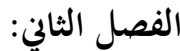

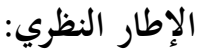

المبحث الأول: التعليم عن بعد

وقد يرى بعض المعلمين أن التعليم عن بعد سيعمل على إلغاء دور المعلم في العملية التعليمية، والحقيقة أن التعليم عن بعد زاد من أهمية التعليم، وجعل دوره أكثر أهمية وأكثر صعوبة، فالمعلم في التعليم عن بعد هو شخص مبدع ذبع ذو كفاءة عالية، ويدير

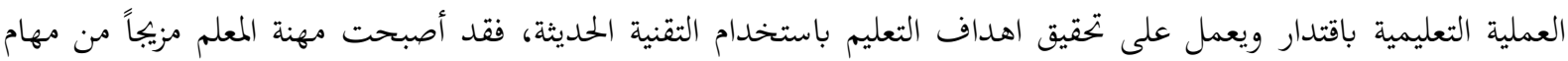

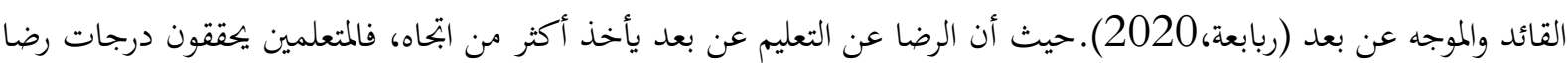

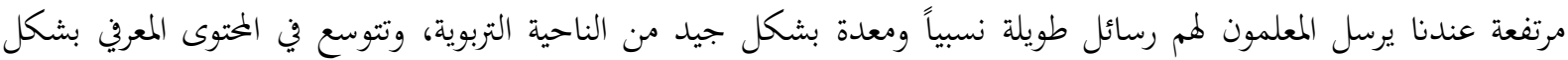

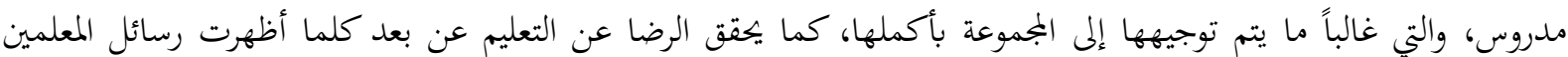

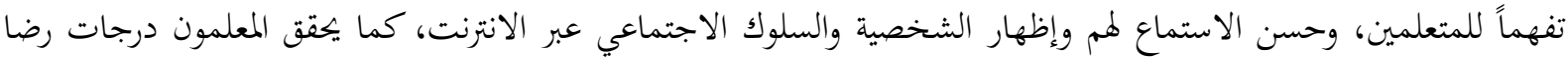

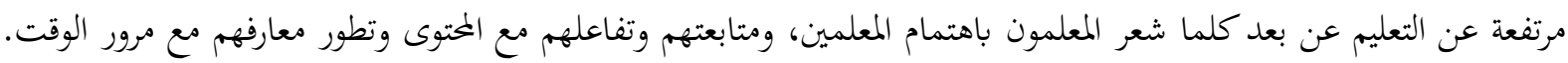
( قرعان، 2021).

ويرى (2020،Yulia) أن التعليم عن بعد سيكون نمط التعليم في المستقبل لأنه يسجم مع طبية الطلبة في هذا العصر،

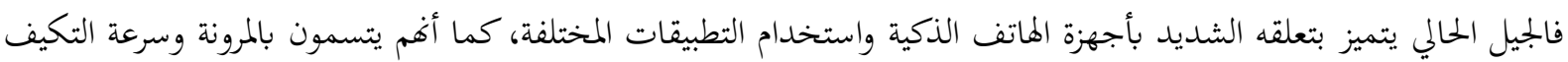

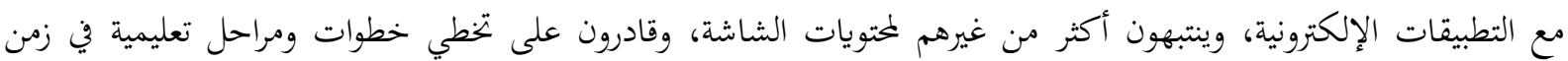
قياسي، ويستطيعون تداول معارف مكثفة خلال تفاعلهم مع التطبيقات الإلكترونية. وعرفه (العتببي، 2019) بأنه توظيف تكنولوجيا الاتصال بواسطة الانترنت في التعاليم، فهو نظام تعليمي يساعد على توصيل المعلومات إلى مكان تواجد المتعلم. ويعرف (2018،Berg \& Simonson ) بأهما منظومة تفاعلية ترتبط بالعملية التعليمية التعلمية، وتقوم هذه المنظومة بالاعتماد على وجود بيئة إلكترونية رقمية تعرض للطالب المقررات والأنشطة بواسطة الشبكات الالكترونية والأجهزة الذكية.

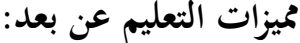

- عدم حصر الطلاب باختيار جامعة في منطقة جغرافية معينة، وبذلك تزداد اختيارات البرامج الدراسية أمام الطالب. - زيادة إمكانية الاتصال بين الطلبة فيما بينهم وبين المعلمين والمدرسة، من خلال بجالس النقاش وغرف الحوار على سبيل المثال.

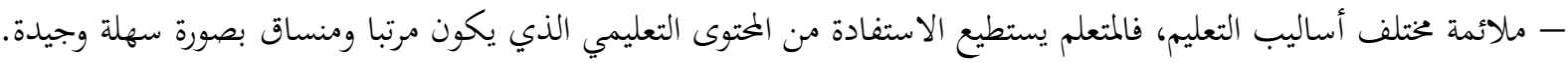
- توفير فرصة أكبر للطلاب غير القادرين كذوي الاحتياجات الخاصة من التعلم في جامعات مرموقة.

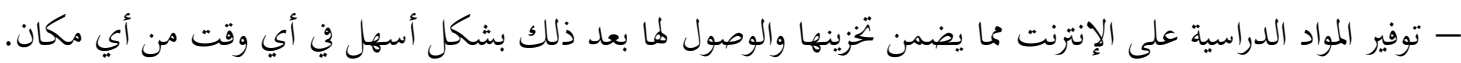
- توفير فرصة أكبر للطلاب للعمل بالسرعة التي يفضلوها.

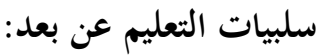

1. عياب القدوة والتأثر بالمعلم في هذا النوع من التعليم. 2. لا يمكن هذا النوع من التعليم من اكتشاف المواهب والقدرات لدى لئ المتعلمين. 3. لا ينمي القدرة اللفظية لدى المتعلم. 


$$
\begin{aligned}
& \text { 4. قد يتسرب للمتعلم الملل من طول الجلوس أمام الأجهزة. } \\
& \text { 5. التعلم عن بعد يضعف العلاقات الاجتماعية لدى المتعلم. } \\
& \text { 6. غياب الجانب الانساني في العملية التعليمية لغيابه في الآلة. } \\
& \text { 7. يؤثر التعليم عن بعد على الناحية الصحية لدى المتعلم. }
\end{aligned}
$$

8. تتطلب هذا النمط من التعليم من الطالب الدراية الكافية باستخدام التكنولوجيا وكيفية الاستفادة من المادة التعليمية. 9. غياب فرصة التواصل الجيد مع الاساتذة للإجابة عن استفساراتم حول ما يدرسوه ( محمد، 2020).

معيقات التعليم عن بعد:

أثبت التجربة أن بعض المعلمين والأهالي والطلبة غير مهيئين لتعليم عن بعد، وأبرزت المتابعة بشأن الحصص عبر برامج

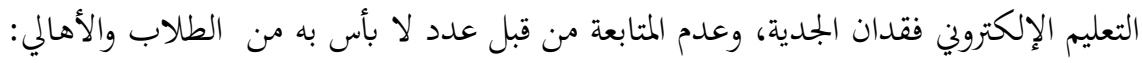
الطلبة: شعر الطلاب بعدم كفاءة التعلم عن بعد، فقد تفاوتت درجة جديتهم من طالب إلى آخر، ويرون أن العبء الدراسي قد تضاعف، وأفم يعانون من ضغط نفسي كبير لأفم لا يعرفون ماذا يفعلون، وكيف يدرسون، بالإضافة إلى الضغط

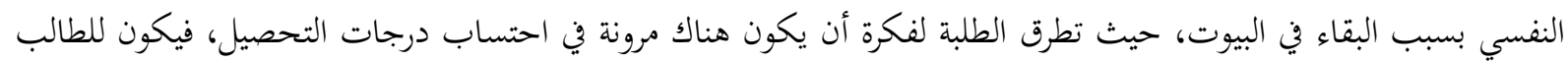

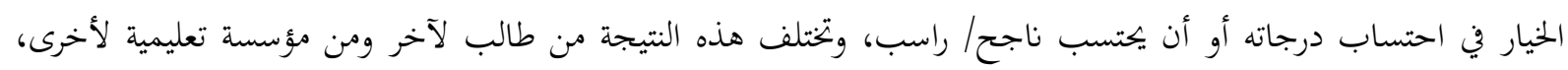

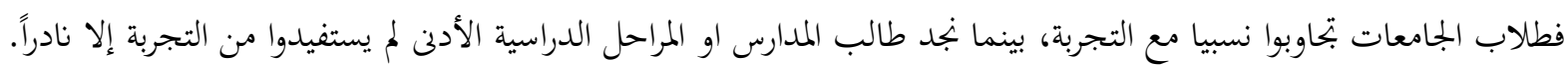
الأهالي: لم يعتادوا هذا الكم أو النوع من التعلم الذاتي داخل البيت، مع صفوف ومراحل تعليمية مختلفة، وتقع على عاتق والوالدين عبئ التعليم والمراقبة والمواكبة لتعلم الأبناء، خاصة في الصفوف الأولى، بالإضافة لشبكات الإنترنت التي لا تستوعب هذا

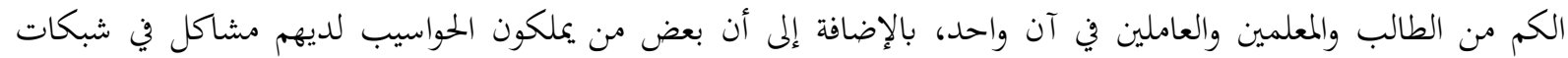

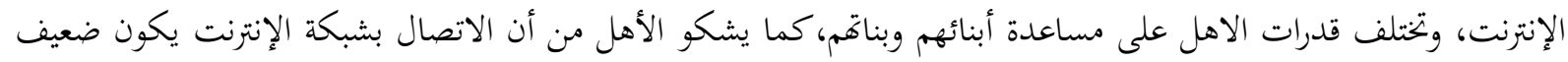

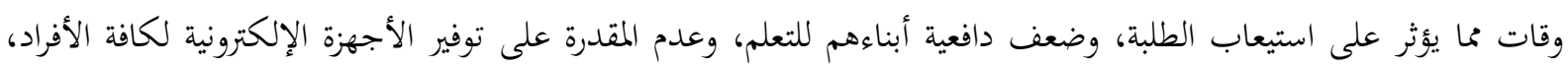

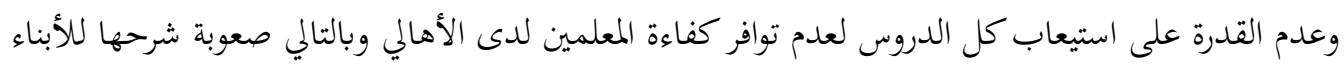
المعلمين: يختلف دور المعلم في التعليم التقليدي عن دوره بالتعليم الإلكتروني، فيتطلب منه التعامل مع الوسائل التكنولوجية الحديثة ليتمكن من توظيفها بشكل جيد في العملية التعليمية، ويتطلب منه اتباع استراتيجيات تعليمية تناسب بيئة التعليم الإلكتروني منها: التعلم التعاوني، والنقاش، والتعلم التشاركي، والمحاضرة الإلكترونية، والعروض العلمية لبرجيات الوسائط المتعددة،

$$
\text { التعلم بمحاكاة لعب الأدوار بالويب (جريد، 2020) }
$$

مبررات التعليم عن بعد:

إن تعالي الأصوات التي تطالب بالتعليم عن بعد له مبررات منها أورده الشرهان (2014) كما يلي: - التوجيهات العالمية وتوصيات المنظمات المختصة بالتعليم: فقد طالبت الكثير من المنظمات العالمية المختصة بالتعلم على

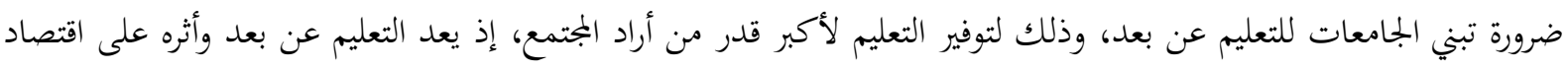

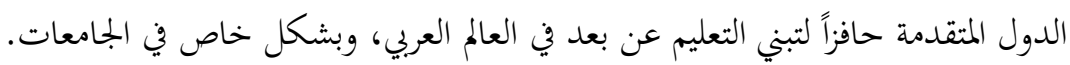
- مبررات اجتماعية وثقافية: إن التعليم عن بعد يتيح فرصة التعليم لمن لم يحالفهم الحظ في الالتحاق بالجامعة نتيجة لبعض التقاليد والظروف الاجتماعية، ففي التعليم عن بعد يستطيع العامل والأم الحامل وربة البيت والسجين من مواصلة التعليم. 
- مبررات بشرية وجغرافية: يتيح التعليم عن بعد التحاق طالب في قرية فقيرة في البادية من الالتحاق بجامعة في الولايات المتحدة

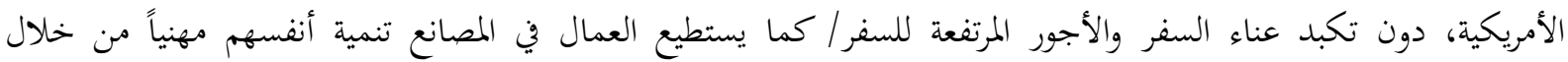
الالتحاق بدورات تدريبية عن بعد.

- مبررات إنسانية ونفسية: إن التعليم عن بعد يحقق غاية سامية، إذ يوفر فرصة التعليم لمن حرم منها، ويحقق التعليم للجميع، وهو مرن يستطيع تحقيق رغبات المتعلمين المتنوعة، ويمكن أن يسترجعه المتعلم ويحفظه بسهولة. - مبررات اقتصادية: فالتعليم عن بعد اقتصادي وغير مكلف، فالتكاليف التواصل مجانية في بعض الدول، كما أنه لا يتطلب شراء مواد دراسية، ويمكن حفظه واسترجاعه بسهولة ويسر. - مبررات سياسية: ويمكن الاحساس بهذا المبرر خلال جائحة كورونا، فالتعليم عن بعد قد يكون الخيار الوحيد لاستمرار التعلم في الحروب والصراعات، والظروف الطارئة مثل انتشار الأوبئة والكوارث الطبيعية.

\section{الحلول التي يمكن استخدامها للتغلب على المعيقات التي يمكن أن توجه التعليم ما بعد كورونا} 1. التوسع في التعليم عن بعد وتكنولوجيا المعلومات، والتوسع في استخدام المنصات التي يمكن تقديم الدروس من خلالها، والتوسع في مكينة الامتحانات من خلال التوسع في انشاء بنوك للأسئلة وتطبيق التصحيح الآلي والعمل على ربط المؤسسات التعليمية المدارس والجامعات بشبكة اتصالات موحدة.

2. تطوير البنية التحتية والتكنولوجية وهو ما يطلب ضرورة تحديث البنية التحتية بالمؤسسات خاصة في المناطق الفقيرة حتى يمكنهم الحصول على الحخدمات المقدمة عن طريق التعليم عن بعد، وتوفير اللازم لاستكمال تغطية المحافظات بكابلات الالياف الضوئية

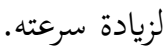

3. توفير مزيد من الاجراءات الاحتزازية الصحية وتوعية الافراد بأهمية وضرورة الالتزام بها، ولعل ذلك يتطلب ان تقوم الاجهزة

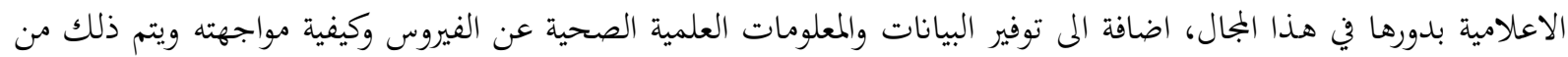
خلال تضمين تلك المعلومات في المقررات والانشطة في المراحل التعليمية المختلفة. 4. سرعة عقد الدورات التدريبية لأعضاء هيئة التدريس بالمدارس والجامعات لإدارة المناهج الدراسية وفقا للصيغة التي سوف تتبناها كل دولة سواء كانت تعليم عن بعد أو تعليم نختلط، والتوجه نهو تدريب المعلمين على استخدام التكنولوجيا الحديثة في التعليم.

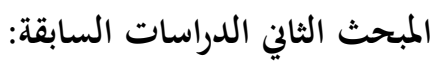

هدفت دراسة قنبي وآخرون (2020) إلى التعرف على واقع التعليم الإلكتروني في فلسطين خال جائحة كورونا (COVID 19)

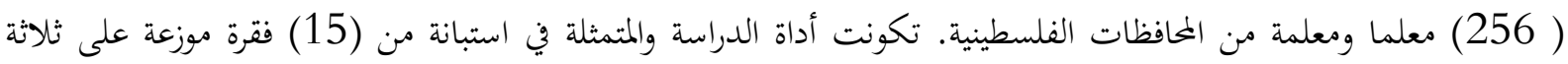
مجالات هي: مجال "المنهاج الفلسطيني"، وبجال "المعلم الفلسطيني والتدريب الإلكتروني"، وبجال "البنية التقنية الفلسطينية والعلاقة

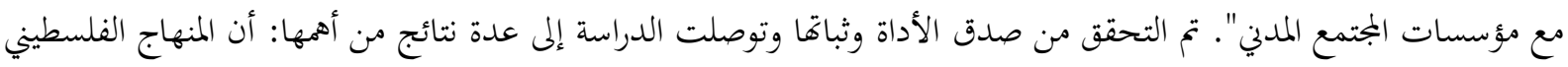

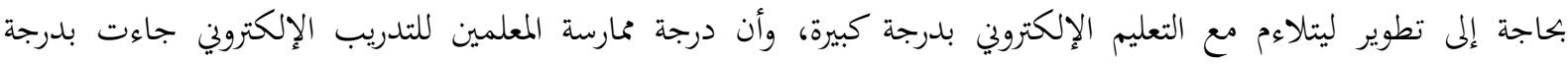

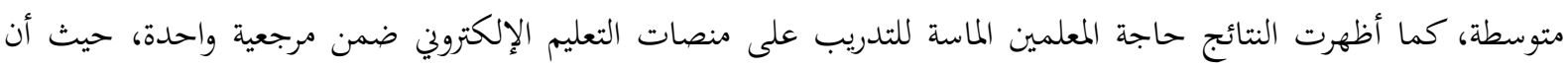

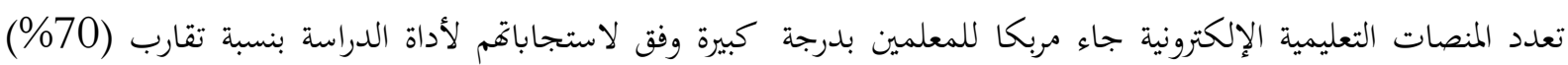

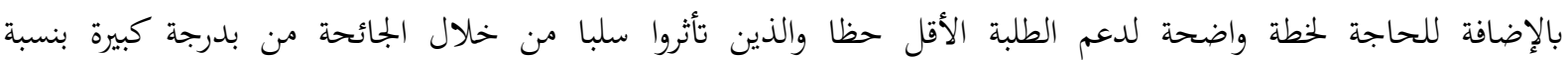


(69.5\%) من المستجيبين لأداة الدراسة. كما أشارت النسب المئوية لنتائج الدراسة أن جهوزية البنية التقنية الفلسطينية تراوحت بين القليلة والمتوسطة ـوفي ضوء هذه النتائج توصي الدراسة بضرورة تطوير المنهاج الفلسطيني من خلال تصميم المحتوى التعليمي

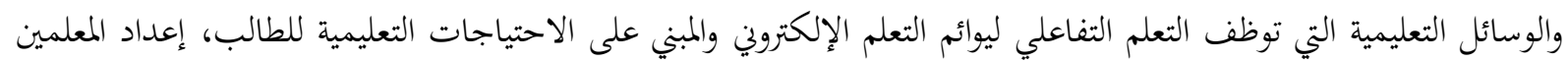

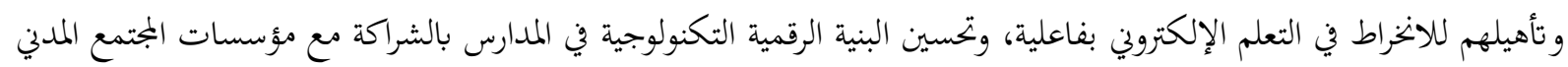
وكافة أطراف الدعم والتمويل المجتمعي والوطني .

وهدفت دراسة ريم (2020) إلى الكشف عن التحديات التي واجهت الأسر السعودية في تعليم أبنائها، واستخلاص

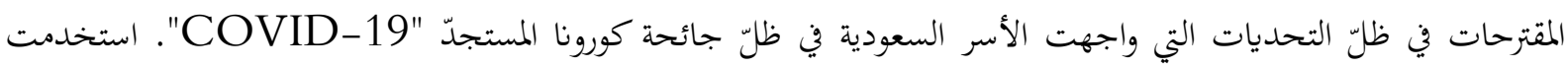
الباحثة المنهج الوصفي المسحي لمناسبته لأهداف الدراسة، وتضمَّن مجتمع البحث الحالي جميع الآباء والأمهات الذين لديهم طلاب أو طالبات بمراحل التعليم العام خلال العام الدراسي. أمّا عينة البحث فقد التهن التملت على (412) فردًا تم اختيارهم

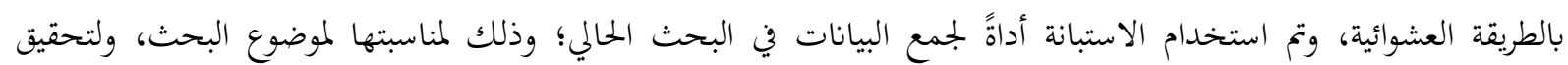

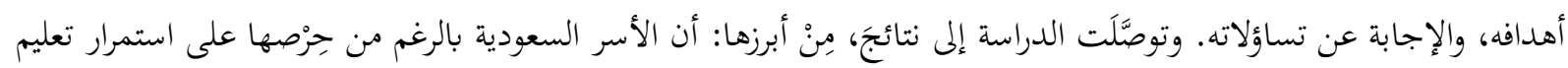

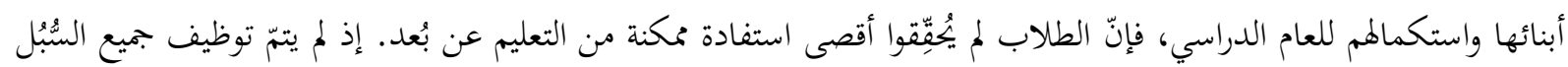

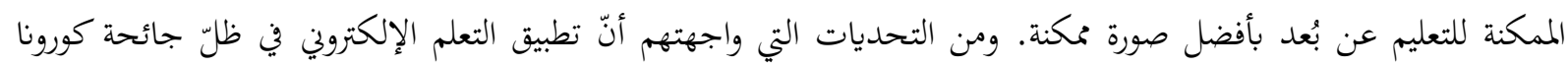

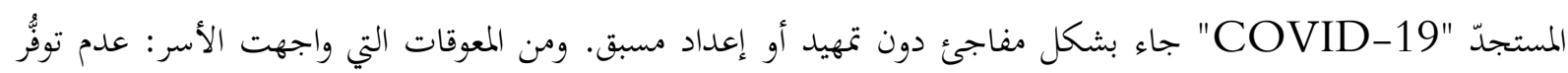

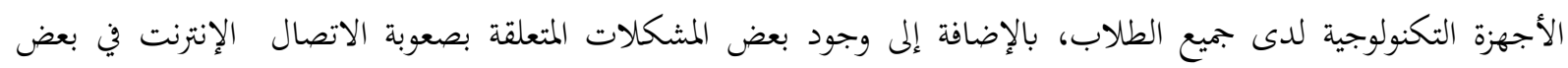
المناطق، وكذلك وجود بعض العوامل المتعلقة بقصور توظيف المعلمين لمهارات استخدام التقنيات الحديثة في التعليم، وأيضًا التكلفة

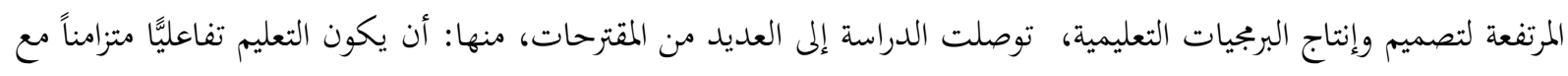

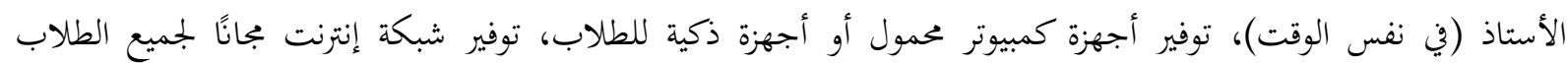

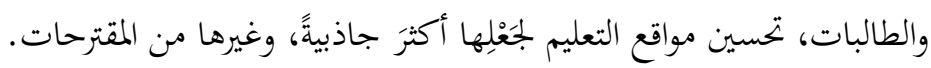
وأجرى ربابعة (2020) دراسة هدفت إلى الكشف عن الدور الذي يؤديه التعليم عن بعد في تنمية التعلم الذاتي لدى طلبة جامعة الزرقاء الخاصة في ظل انتشار فيروس كورونا من وجهة نظرهم، وتكونت عينة الدراسة من (138) طالباً من طلبة

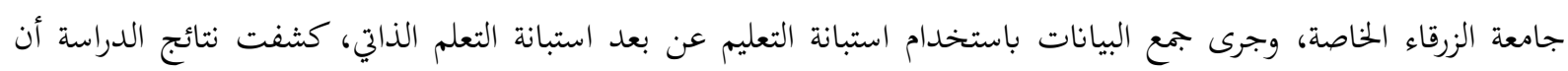

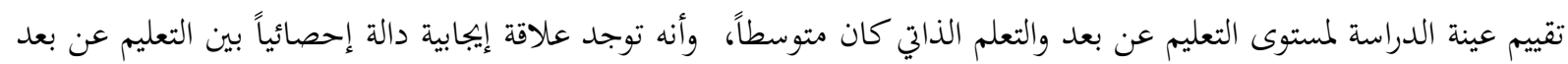

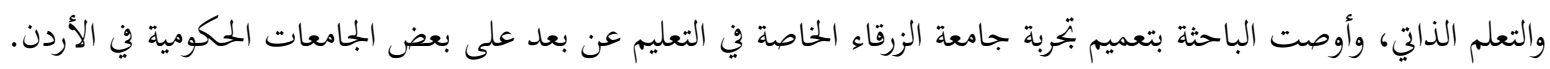

\section{دراسة العتبي (2019): معايير الجودة في أنظمة التعليم الإلكتروبي}

ومن خلال بحث أجراه العتبي (2019) سعى إلى التعرف على مفهوم الجودة ومبادئها، وتسليط الضوء على أهمية

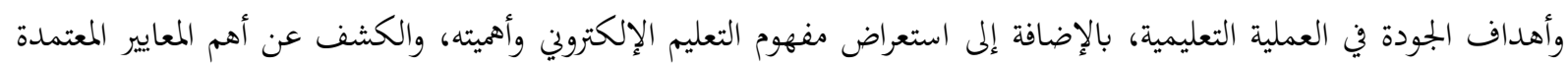

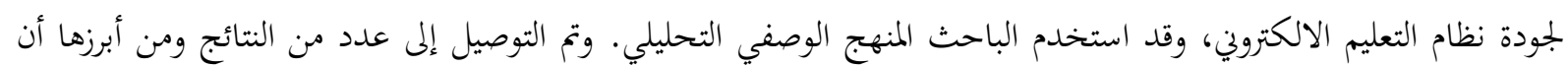

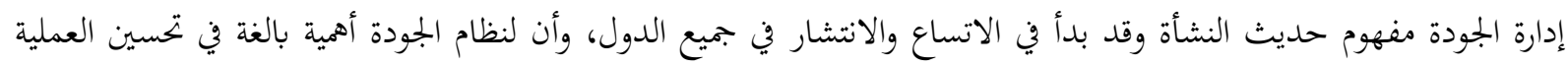

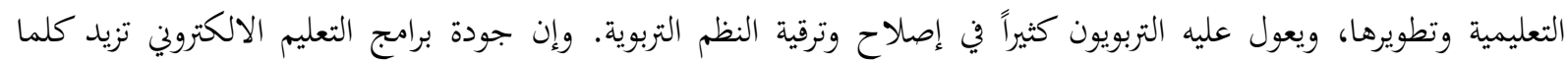

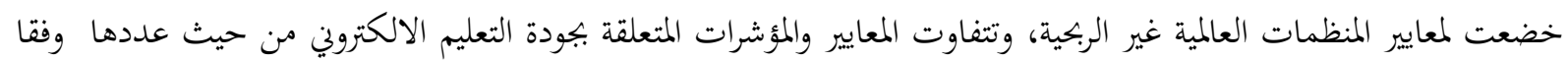
لتنوع الدراسات والمؤسسات التي تناولت هذه المعايير. 
دراسة (19)،Basilaia \& Kvavadze، 2020، ) الانتقال إلى التعليم عبر الإنترنت في المدارس أثناء جائحة فيروس كورونا COVID-19 في جورجيا.

هدفت إلى دراسة بحربة الانتقال من التعليم في المدراس إلى التعليم عن بعد خلال انتار وباء فيروس كورونا في جورجيا، فقد

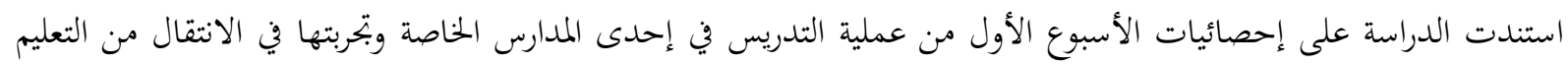

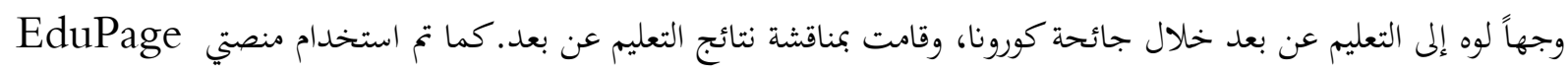

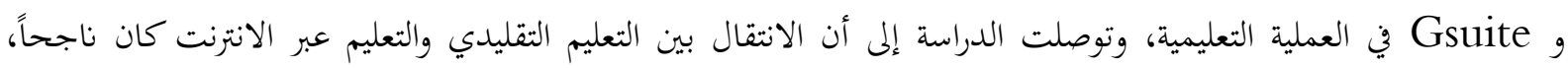

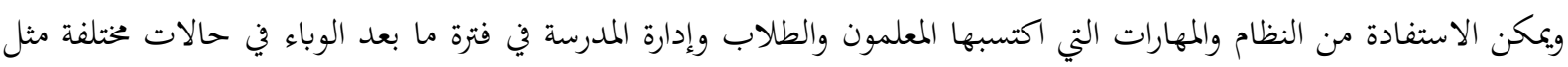

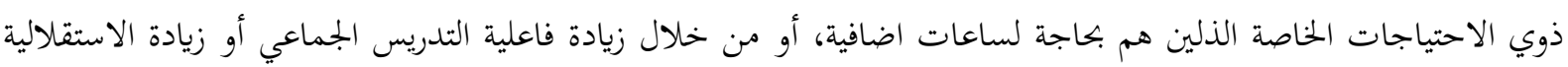

$$
\text { لدى الطالب والحصول على مهارات جديدة. }
$$

دراسة (COVID-19) (2020،Draissi \& Yong) خطة الاستجابة لتفشي مرض الجامعات المغربية وتنفيذ

التعليم عن بعد

وهدفت إلى التعرف إلى خطة الاستجابة لتفشي مرض (COVID-19) في الجامعات المغربية وتنفيذ التعليم عن بعدا،

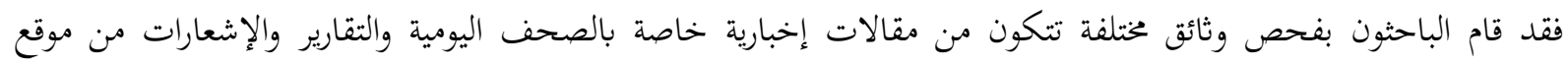

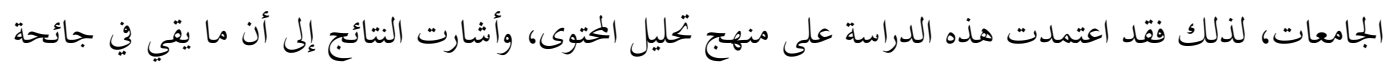

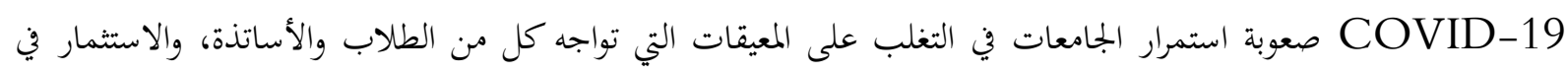

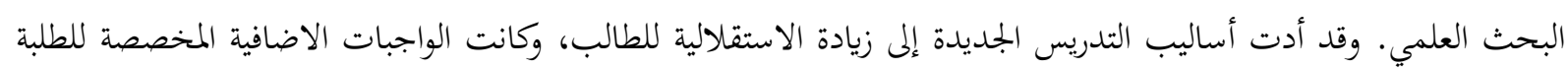

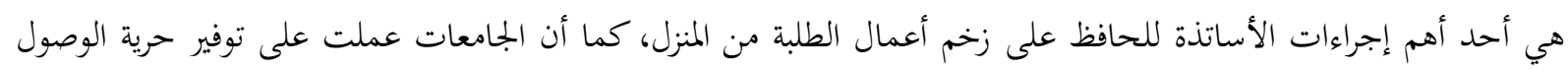

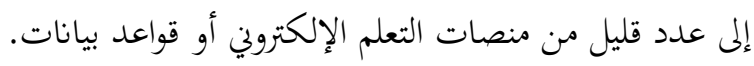




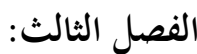

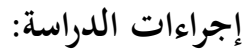

منهجية البحث: استخدم الباحث في هذه الدراسة المنهج الوصفي الذي يعتمد على دراسة الظاهرة في الوقت الحاضر وكما هي في الواقع، وهو المنهج المناسب والأفضل لمثل هذه الدراسات. مجتمع البحث: يتكون مجتمع الدراسة من طلبة المعاهد العليا في منطقة بئر السبع. عينة البحث: تتكون العينة من 150 من طلبة المعاهد العليا في منطقة بئر السبع، وقد تم اختيارهم بالطريقة العشوائية، والجدول رقم (1) يبين خصائص العينة الديموغرافية: جدول (1): خصائص العينة الديموغرافية

\begin{tabular}{|c|c|c|c|}
\hline النسبة & العدد & مستويات المتغير & المتغير \\
\hline 15.3 & 23 & ذكر & \multirow{2}{*}{ الجنس } \\
\hline 84.7 & 127 & انثى & \\
\hline 61.3 & 92 & لقب أول & \multirow{3}{*}{ المرحلة التدريسية في } \\
\hline 8.0 & 12 & لقب ثاني & \\
\hline 30.7 & 46 & شهادة تدريس & \\
\hline 58.0 & 87 & أولى & \multirow{4}{*}{ السنة الدراسية في } \\
\hline 6.0 & 9 & ثانية & \\
\hline 16.7 & 25 & ثالثة & \\
\hline 19.3 & 29 & رابعة & \\
\hline
\end{tabular}

أداة البحث: تم بناء أداة الدراسة على شكل استبانة من خلال الاستفادة من الدراسات السابقة، وقد كانت الاستبانة مكونة من (37) فقرة تشترك جميعها في قياس درجة فاعلية التعلم عن بعد في ظل تفشّي فيروس الكورونا من وجهة نظر طلبة المعاهد العليا في منطقة بئر السبع.

وقد تم تقسيمها إلى أربعة محاور: وهي: استمرارية التعلم عن بعد في ظل تفشّي فيروس كورونا، ومعيقات التعليم الإلكتروين من وجهة نظر الطلبة، وتفاعل أعضاء هيئة التدريس مع التعليم عن بعد في ظل ازمة كورونا من وجهة نظر الطلبة، وتفاعل الطلبة مع التعلم عن بعد في ظل التعليم الإلكتروني وبعد عرضها وإجراء التعديلات اللازمة من إضافة وحذف تم اعته اعتمادها بصيغتها النهائية بناء على طلب المحكمين.

صدق أداة البحث (صدق البناء): تم التحقق من صدق أداة الدراسة بعرضها على مجموعة من المحكمين من ذوي الاختصاص،

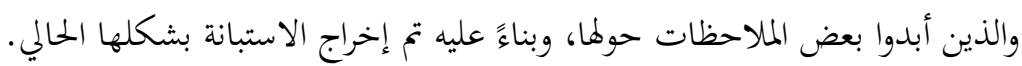
ثبات أداة البحث: تم حساب الثبات بطريقة الاتساق الداخلي وبحساب معادلة الثبات كرونباخ ألفا، حيث بلغت قيمة الثبات (0.944) وبذلك تتمتع الاستبانة بدرجة جيد جداً من الثبات. 


\begin{tabular}{|c|c|}
\hline الدرجة & المتوسط الحسابي \\
\hline منخفضة & $2.33-1.00$ \\
\hline متوسطة & $3.67-2.34$ \\
\hline مرتفعة & $5.00-3.68$ \\
\hline
\end{tabular}

متغيرات البحث:

المتغير التابع: درجة فاعلية التعلم عن بعد في ظل تفشّي فيروس الكورونا من وجهة نظر طلبة المعاهد العليا في منطقة بئر السبع. المتغيرات التصنيفية: الجنس، المرحلة التدريسية في الكلية، السنة الدراسة في الكلية.

الفصل الرابع: النتائج والاستنتاجات والتوصيات نتائج السؤال الرئيس: ما درجة فاعلية التعلم عن بعد في ظل تفشّي فيروس الكورونا من وجهة نظر طلبة المعاهد العليا في منطقة بئر السبع؟ للإجابة عن السؤال السابق تم استخراج المتوسطات الحسابية والانحرافات المعيارية لقياس درجة فاعلية التعلم عن بعد في

ظل تفشّي فيروس الكورونا من وجهة نظر طلبة المعاهد العليا في منطقة بئر السبع، وذلك كما هو موضح في الجدول رقم (2). جدول (2): المتوسطات الحسابية الاخرافات المعيارية لدرجة فاعلية التعلم عن بعد في ظل تفشّي فيروس الكورونا من وجهة نظر طلبة المعاهد العليا في منطقة بئر السبع

\begin{tabular}{|c|c|c|c|}
\hline 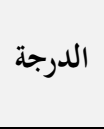 & 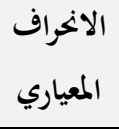 & المتوسط & 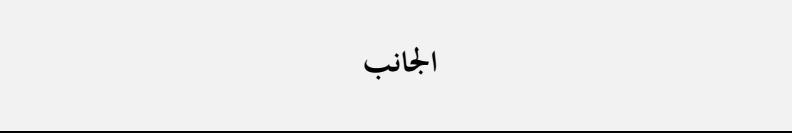 \\
\hline 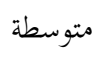 & 0.87 & 3.56 & المجال الأول: استمرارية التعلم عن بعد في ظل تفشّي فيروس كورونا. \\
\hline 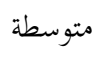 & 0.52 & 3.23 & المجال الثاني: معيقات التعليم الإلكتروني من وجهة نظر الطلبة . \\
\hline 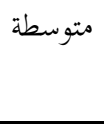 & 0.78 & 3.53 & المجال الثالث: تفاعل أعضاء هيئة التدريس مع التعليم عن بعد في ظل ازمة \\
\hline 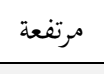 & 0.93 & 3.74 & المجال الرابع: تفاعل الطلبة مع التعلم عن بعد في ظل التعليم الإلكتروين \\
\hline 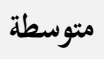 & 0.64 & 3.52 & 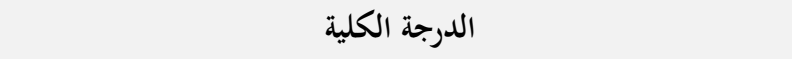 \\
\hline
\end{tabular}

نلاحظ من الجدول السابق ومن خلال المعطيات الواردة في الجدول أن درجة فاعلية التعلم عن بعد في ظل تفشّي فيروس

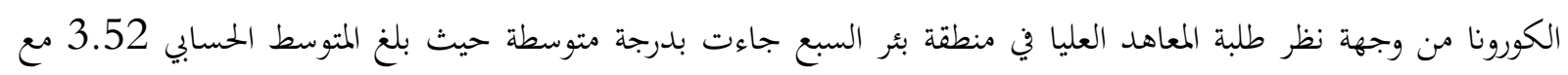
انخراف معياري 0.64 وقد كانت أهم الأبعاد (تفاعل الطلبة مع التعلم عن بعد في ظل التعليم الإلكتروني) بمتوسط حسابي 3.74 مع انحراف

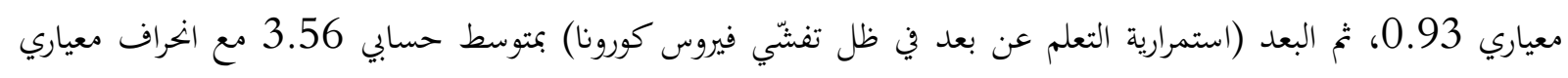

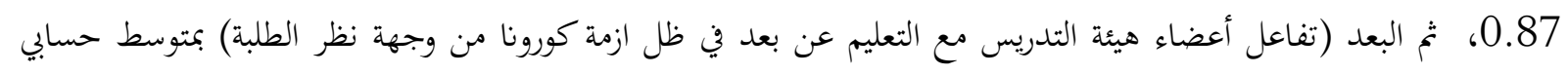

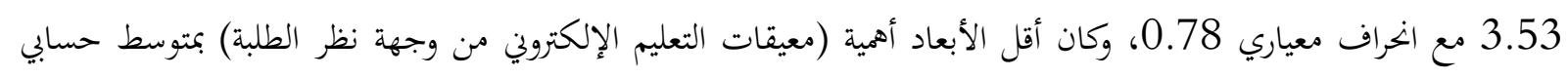

$$
\text { 3.23 مع انخراف معياري } 0.52 .
$$


نتائج السؤال الأول: ما درجة استمرارية التعلم عن بعد في ظل تفثّي فيروس كورونا من وجهة نظر طلبة المعاهد العليا في منطقة بئر السبع؟ للإجابة عن السؤال السابق تم استخراج المتوسطات الحسابية والانحرافات المعيارية لدرجة استمرارية التعلم عن بعد في ظل تفشّي فيروس كورونا من وجهة نظر طلبة المعاهد العليا في منطقة بئر السبع، وذلك كما هو موضح في الجدول رقم (3) (3). جدول (3): المتوسطات الحسابية الانحرافات المعيارية لدرجة استمرارية التعلم عن بعد في ظل تفشّي فيروس كورونا من وجهة نظر طلبة المعاهد العليا في منطقة بئر السبع مرتبة حسب الأهمية

\begin{tabular}{|c|c|c|c|}
\hline الدرجة & 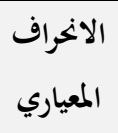 & المتوسط & 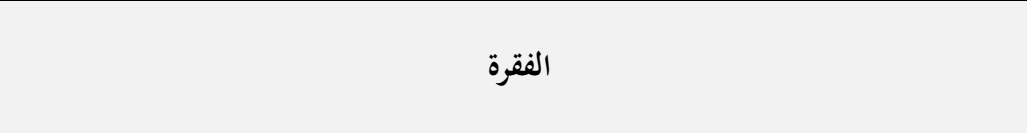 \\
\hline مرتفعة & 1.18 & 3.84 & تم توفير دليل لاستخدام الموقع الخاص بالمادة التعليمية للطلبة \\
\hline 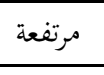 & 0.93 & 3.76 & يمتلك المحاضرون مهارات كافية لتصميم وإنتاج محتوى الكتروني فعّال \\
\hline 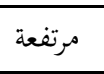 & 1.05 & 3.71 & يسهل تصميم الموقع الذي وفرته الكلية للتعليم الإلكتروني عرض المادة بطريقة شيقة \\
\hline 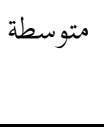 & 1.49 & 3.65 & أشعر بالرضا عن استخدام نظام التعلم عن بعد كبديل عن نظام التعلم الوجاهي في ظل وباء \\
\hline متوسطة & 1.08 & 3.65 & تسهم تقنية التعلم عن بعد بفاعلية في استمرارية ونجاح العملية التعليمية في ظل أزمة كورونا \\
\hline 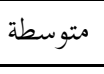 & 1.09 & 3.62 & تتم عملية تبادل المواد التعليمية دون عوائق فنية \\
\hline 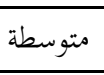 & 1.18 & 3.56 & توفر الكلية الدعم الفني الملائم لتسهيل توظيف التكنولوجيا في المادة التعليمية \\
\hline 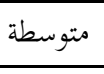 & 1.27 & 3.54 & هناك سلاسة في الانتقال من التعليم التقليدي إلى التعليم عن بعد في ظل أزمة كورونا \\
\hline متوسطة & 1.21 & 3.53 & تم تدريب الطلبة من قبل الكليات على استخدام التعلم عن بعد من خلال اعطائهم بعض المساقل التهيلية خلاءل الوباء \\
\hline 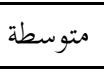 & 1.11 & 3.51 & تقوم إدارة الكلية بتقييم مستمر لآلية التدريس عن بعد \\
\hline 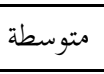 & 1.33 & 3.44 & نظام التعلم عن بعد يوفر تواصلا بين الطلبة والمحاضرين \\
\hline 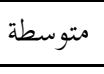 & 0.99 & 3.38 & التقنيات المتبعة في التعلم عن بعد فعالة تغطي كافة جوانب الخطة الدراسية للمساقات \\
\hline متوسطة & 1.28 & 2.84 & يتم تدريب الطلبة على التعلم الالكتروني من خلال دورات أو مساقات تأهيلية أو ورشات عمل \\
\hline متوسطة & 0.87 & 3.56 & 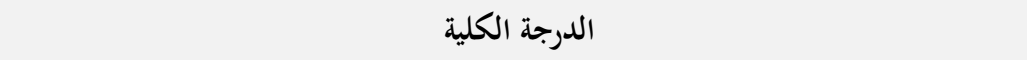 \\
\hline
\end{tabular}

نلاحظ من الجدول السابق ومن خلال المعطيات الواردة في الجدول أن درجة استمرارية التعلم عن بعد في ظل تفشيّي

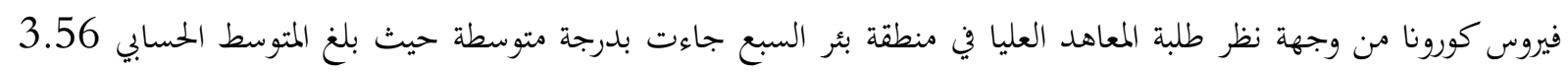
مع انخراف معياري 0.87

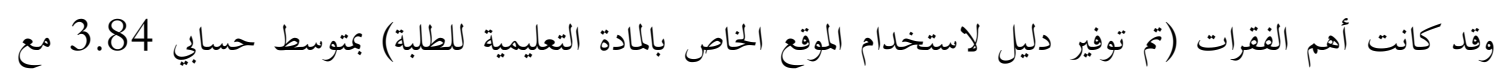

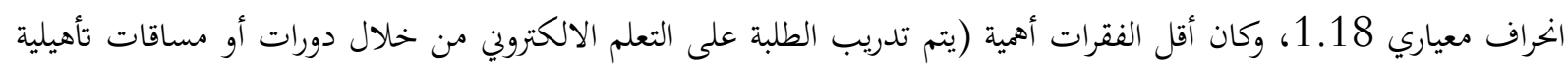

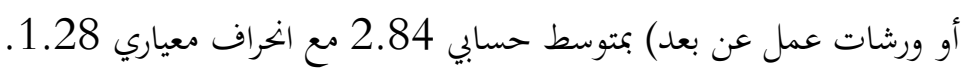

نتائج السؤال الثاني: ما درجة معيقات التعليم الإلكتروبي من وجهة نظر طلبة المعاهد العليا في منطقة بئر السبع؟ للإجابة عن السؤال السابق تم استخراج المتوسطات الحسابية والانحرافات المعيارية لدرجة معيقات التعليم الإلكتروني من

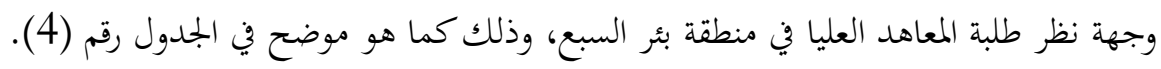


جدول (4): المتوسطات الحسابية الانحرافات المعيارية لدرجة معيقات التعليم الإلكتروني من وجهة نظر طلبة المعاهد العليا في منطقة بئر السبع مرتبة حسب الأهمية

\begin{tabular}{|c|c|c|c|}
\hline الدرجة & الإنراف & المتوسط & الفقرة \\
\hline مرتفعة & 1.29 & 3.72 & تم عقد مساقات تدريبية وإعداد الطلاب قبل أزمة الكورونا لآلية استخدام التعليم الإلكتروي من قِبل \\
\hline مرتفعة & 1.04 & 3.62 & جميع المحاضرين لديهم الخبرة والمهارات الكافية والمناسبة لاستخدام الحاسوب، الانترنت والادوات \\
\hline 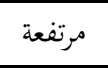 & 1.09 & 3.55 & يتناسب نظام التعلم عن بعد مع نوع المواد بشقيها النظري والعملي \\
\hline متوسطة & 1.11 & 3.43 & تأثر تفاعل الطلبة مع التعليم الإلكتروبي والمحاضرات بسبب ظروف معيشية صعبة او خاصة عند \\
\hline 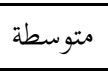 & 1.22 & 3.29 & سرعة الانترنت مناسبة في بيتي وأستطيع حضور أي محاضرة دون أي انقطاع \\
\hline 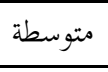 & 1.28 & 3.16 & تواجه المحاضرين مشاكل في التعليم عبر برنامج الزوم من وجهة نظرك \\
\hline متوسطة & 1.02 & 3.08 & 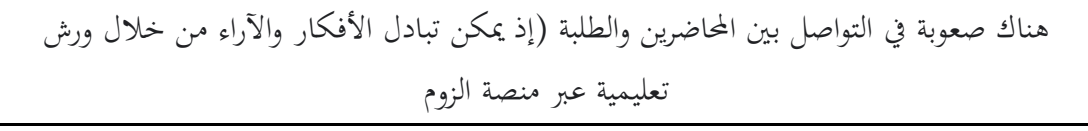 \\
\hline متوسطة & 1.18 & 3.01 & هناك صعوبة لدى المحاضرين في متابعة الأعداد الكبيرة للطلبة خلال المساق عبر أدوات التعليم عن \\
\hline متوسطة & 0.52 & 3.23 & الدرجة الكلية \\
\hline
\end{tabular}

نلاحظ من الجدول السابق ومن خلال المعطيات الواردة في الجدول أن درجة معيقات التعليم الإلكتروني من وجهة نظر

طلبة المعاهد العليا في منطقة بئر السبع جاءت بدرجة متوسطة حيث بلغ المتوسط الحسابي 3.23 مع الخراف معياري 0.52 وقد كانت أهم الفقرات (تم عقد مساقات تدريبية وإعداد الطلاب قبل أزمة الكورونا لآلية استخدام التعليم الإلكتروني من

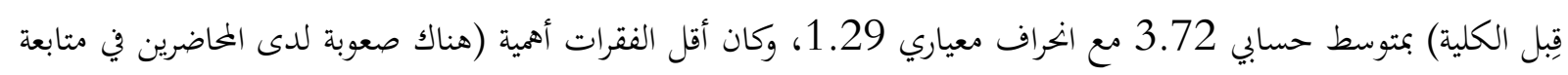

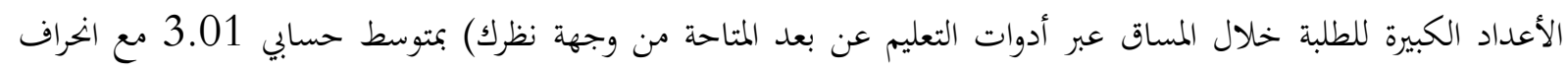
معياري 1.18.

نتائج السؤال الثالث: ما درجة تفاعل أعضاء هيئة التدريس مع التعليم عن بعد في ظل ازمة كورونا من وجهة نظر طلبة

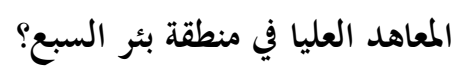

للإجابة عن السؤال السابق تم استخراج المتوسطات الحسابية والانخرافات المعيارية لدرجة تفاعل أعضاء هيئة التدريس مع

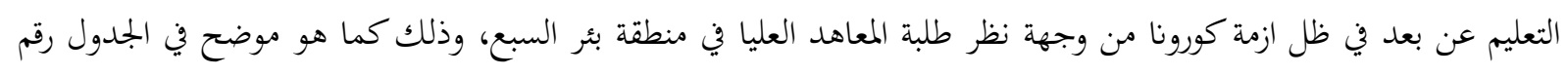

جدول (5): المتوسطات الحسابية الانحرافات المعيارية لدرجة تفاعل أعضاء هيئة التدريس مع التعليم عن بعد في ظل ازمة

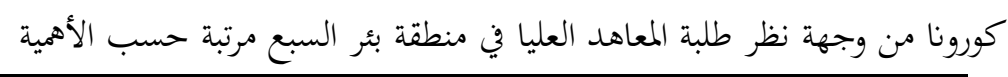

\begin{tabular}{|c|c|c|c|}
\hline 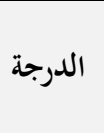 & الالانحراف & المتوسط & 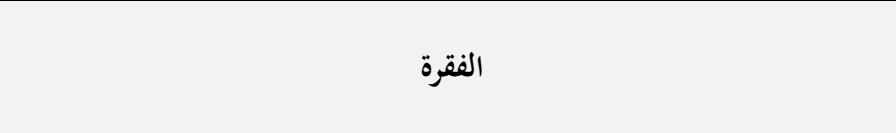 \\
\hline 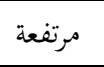 & 0.99 & 4.11 & يجيب المحاضر عن استفسارات الطلبة عن المادة العلمية المرفقة في موقع المساق \\
\hline 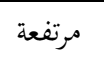 & 0.91 & 3.88 & يشتمل المتوى التعليمي على اضافة تمارين وواجبات تساعد على التعلم بشكل عا \\
\hline
\end{tabular}




\begin{tabular}{|c|c|c|c|}
\hline 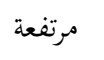 & 0.99 & 3.84 & يتم إرفاق المادة التعليمية للطلبة بسهولة ويسر في موقع الكلية \\
\hline متوسطة & 1.02 & 3.66 & تتوافق خطة المساق عن بعد مع التعلم الوجاهي \\
\hline 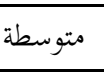 & 1.11 & 3.39 & يقوم المحاضرون بتنويع أساليب التقييم \\
\hline 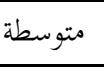 & 1.03 & 3.39 & يتم تقييم الطالب بشكل مستمر اثناء عملية التعلم عن بعد من وجهة نظرك \\
\hline 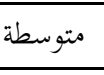 & 1.12 & 3.36 & يعتقد الطلبة أن الاختبارات عن بعد وسيلة مناسبة لتقييم التحصيل العلمي \\
\hline 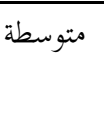 & 1.32 & 3.34 & التعلم عن بعد أكثر فاعلية من حيث استغلال الوقت أكثر من التعليم التقليدي من وجهة \\
\hline 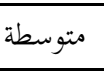 & 1.25 & 3.23 & هناك مصداقية عالية في تقييم الطلبة من وجهة نظرهم من خلال نظام التعلم عن بعد \\
\hline 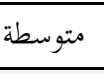 & 1.23 & 3.16 & يبدي المحاضرون رضاهم عن نظام التعلم الإلكتروني من وجهة نظرك \\
\hline 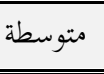 & 0.78 & 3.53 & 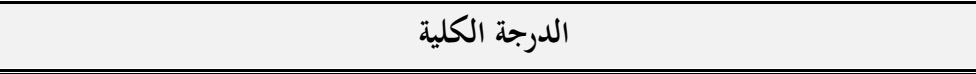 \\
\hline
\end{tabular}

نلاحظ من الجمدول السابق ومن خلال المعطيات الواردة في الجدول أن درجة تفاعل أعضاء هيئة التدريس مع التعليم عن بعد في ظل ازمة كورونا من وجهة نظر طلبة المعاهد العليا في منطقة بئر السبع جاءت بدرجة متوسطة حيث إند بلغ بلغ المتوسط الحسابي

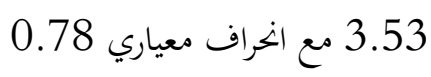
وقد كانت أهم الفقرات (يجيب المحاضر عن استفسارات الطلبة عن المادة العلمية المرفقة في موقع المساق) بمتوسط حسابي

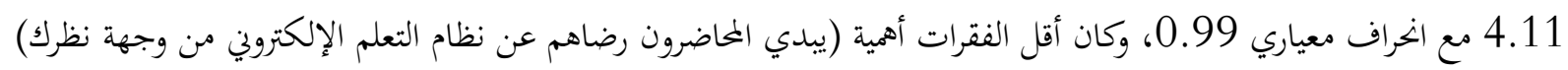
بمتوسط حسابي 3.16 مع انحراف معياري 1.23.

نتائج السؤال الرابع: ما درجة تفاعل الطلبة مع التعلم عن بعد في ظل التعليم الإلكتروبي من وجهة نظر طلبة المعاهد العليا في منطقة بئر السبع؟ للإجابة عن السؤال السابق تم استخراج المتوسطات الحسابية والانحرافات المعيارية لدرجة تفاعل الطلبة مع التعلم عن بعد

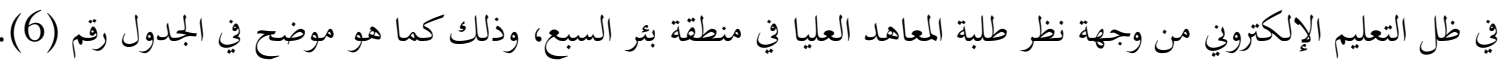

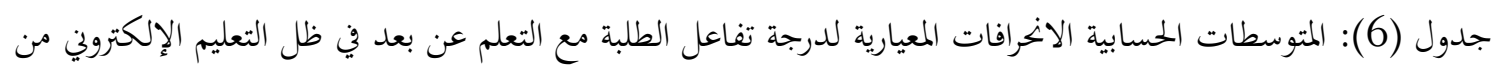
وجهة نظر طلبة المعاهد العليا في منطقة بئر السبع مرتبة حسب الأهمية

\begin{tabular}{|c|c|c|c|}
\hline 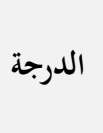 & الالمعراف & المستوسط & 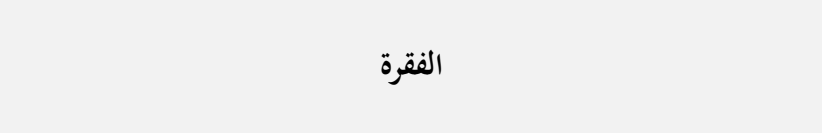 \\
\hline مرتفعة & 0.92 & 4.11 & يتيح نظام التعلم عن بعد للطالب الوصول للمادة التعليمية في أي وقت \\
\hline 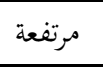 & 1.12 & 3.78 & يستطيع الطالب طرح أي تساؤلات واستفسارات من خلال التعلم عن بعد \\
\hline مرتفعة & 1.11 & 3.77 & أتفاعل مع نظام التعلم عن بعد بشكل مستمر \\
\hline 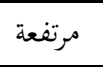 & 1.16 & 3.71 & عرض المادة الكترونيا يزود الطالب بمهارات اضافية \\
\hline 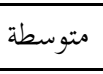 & 1.18 & 3.58 & أشعر بالرضا عن مدى الاستفادة من التعلم عن بعد \\
\hline 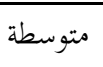 & 1.16 & 3.51 & يساعد أسلوب التعلم الإلكتروني في فهم المادة العلمية بشكل واضح ومفهوم \\
\hline 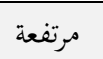 & 0.93 & 3.74 & الدرجة الكلية \\
\hline
\end{tabular}

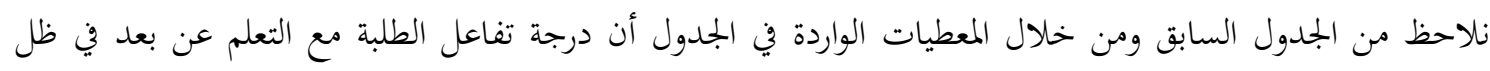

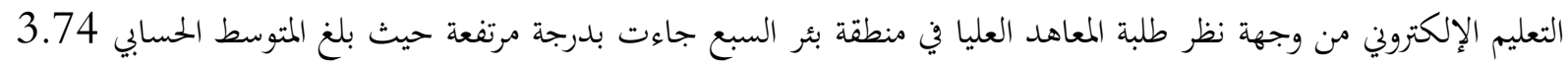
مع انحراف معياري 0.93 
وقد كانت أهم الفقرات (يتيح نظام التعلم عن بعد للطالب الوصول للمادة التعليمية في أي وقت) بمتوسط حسابي 4.11 مع انحراف معياري 0.92، وكان أقل الفقرات أهمية (يساعد أسلوب التعلم الإلكتروني في فهم المادة العلمية بشكل واضح

$$
\text { ومفهوم) بمتوسط حسابي } 3.51 \text { مع انحراف معياري } 1.16 .
$$

نتائج الفرضية الأولى: لا توجد فروق ذات دلالة إحصائية عند مستوى الدلالة (150.05) في متوسطات استجابات أفراد العينة حول درجة فاعلية التعلم عن بعد في ظل تفشّي فيروس الكورونا من وجهة نظر طلبة المعاهد العليا في منطقة بئر السبع

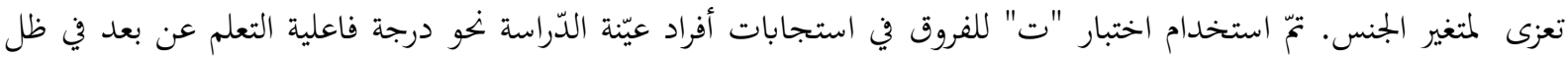
تفشّي فيروس الكورونا من وجهة نظر طلبة المعاهد العليا في منطقة بئر السبع لمتغير الجنس، وقد حصل الباحث على النّائج كما

هي موضّحة في جدول (7).

جدول (7): نتائج اختبار "ت" للفروق في استجابات أفراد عيّنة الدّراسة نحو درجة فاعلية التعلم عن بعد في ظل تفشّي

فيروس الكورونا من وجهة نظر طلبة المعاهد العليا في منطقة بئر السبع تعزى لمتغير الجنس

\begin{tabular}{|c|c|c|c|c|c|c|}
\hline مستوى الدّلالة & قيمة"t" & درجة الحريّة & الانحراف المعياريّ & المتوسّط الحسابيّ & العدد & الجنس \\
\hline \multirow{2}{*}{0.017} & \multirow{2}{*}{-2.408} & \multirow{2}{*}{148} & 0.58 & 3.22 & 23 & ذكر \\
\hline & & & 0.64 & 3.57 & 127 & أنثى \\
\hline
\end{tabular}

تشير المعطيات الواردة في الجدول السّابق أنه توجد فروق ذات دلالة إحصائيّة عند مستوى الدّلالة (0.05 ك م) في

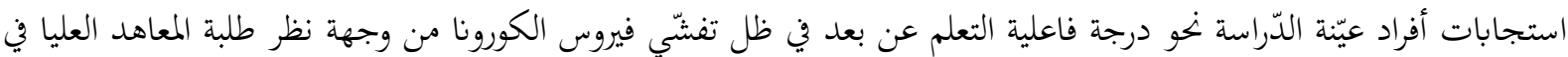

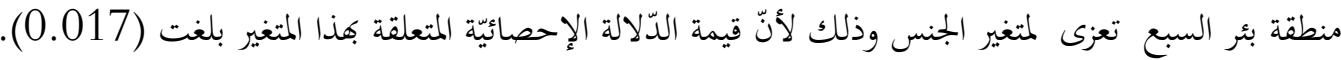
أي أن هذه القيمة أقل من قيمة ألفا (0.05)، وكانت الفروق لصالح الإناث بمتوسط حسابي (3.57) مقابل الذكور

$$
\text { بمتوسط حسابي (3.22). }
$$

الفرضية الثانية: لا توجد فروق ذات دلالة إحصائية عند مستوى الدلالة (20.05) في متوسطات استجابات أفراد العينة حول درجة فاعلية التعلم عن بعد في ظل تفشّي فيروس الكورونا من وجهة نظر طلبة المعاهد العليا في منطقة بئر السبع تعزى لمتغير المرحلة التدريسية في الكلية تمّ استخدام اختبار تحليل التباين الأحادي (One Way ANOVA) للفروق في متوسطات استجابات أفراد

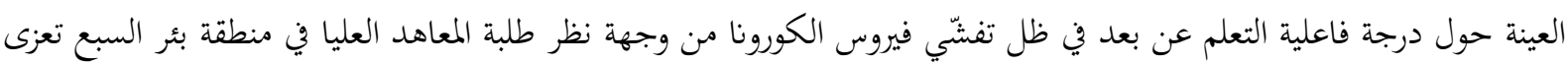

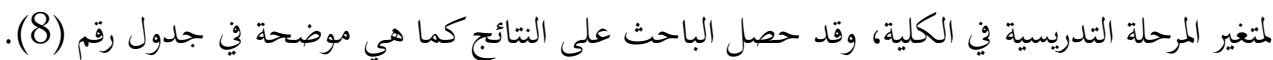
جدول (8): نتائج اختبار تحليل التباين الأحادي للفروق في متوسطات استجابات أفراد العينة حول درجة فاعلية التعلم عن بعد في ظل تفشّي فيروس الكورونا من وجهة نظر طلبة المعاهد العليا في منطقة بئر السبع تعزى لمتغير المرحلة التدريسية في

\begin{tabular}{|c|c|c|c|c|c|}
\hline الإحصائية & قيمة ف & متوسط المربعات & درجات & مجموع المربعات & \\
\hline \multirow{3}{*}{0.000} & \multirow{3}{*}{14.820} & 5.206 & 2 & 10.412 & بين الججموعات \\
\hline & & \multirow[t]{2}{*}{0.651} & 147 & 51.638 & الجموعات \\
\hline & & & 149 & 62.050 & الجمموع \\
\hline
\end{tabular}
الكلية 


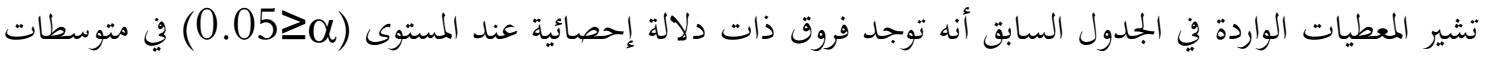
استجابات أفراد العينة حول درجة فاعلية التعلم عن بعد في ظل تفشّي فيروس الكورونا من وجهة نظر طلبة المعاهد العليا في

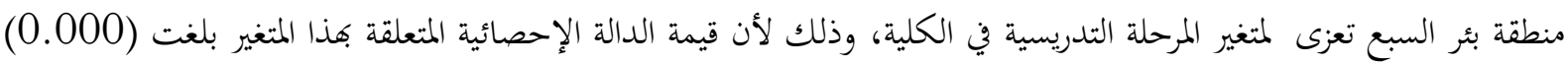
أي أن هذه القيمة أقل من قيمة ألفا (0.05)، وبذلك نرفض الفيع الفرضية الصفرية. ومن أجل دراسة الفروق حول درجة فاعلية التعلم عن بعد في ظل تفشّي فيروس الكورونا من وجهة نظر طلبة المعاهد العليا في منطقة بئر السبع تعزى لمتغير المرحلة التدريسية في الكلية، تم استخدام اختبار توكي (Tukey) للمقارنات الثنائية البعدية، حيث تمثل الأرقام في الجلدول الفروق في الأوساط الحسابية، والجدول التالي يوضح نتائج هذا الاختبار: الجدول رقم (9): نتائج اختبار توكي (Tukey) للمقارنات الثنائية البعدية حول درجة فاعلية التعلم عن بعد في ظل تفشّي فيروس الكورونا من وجهة نظر طلبة المعاهد العليا في منطقة بئر السبع تعزى لمتغير المرحلة التدريسية في الكلية.

\begin{tabular}{|r|r|r|r|}
\hline & لقب & & لقب \\
\hline & & & \\
\hline & & & \\
\hline & & & \\
\hline
\end{tabular}

الفروق دالة إحصائيا عند مستوى 0.05.

من خلال الجدول السابق كانت الفروق بين من يدرسون شهادة التدريس وبين كل من يدرسون (لقب أول، لقب ثاني)

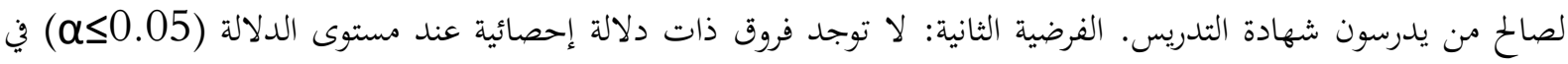

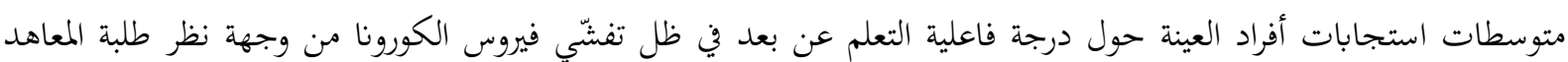
العليا في منطقة بئر السبع تعزى لمتغير السنة الدراسة في الكلية تمّ استخدام اختبار تحليل التباين الأحادي (One Way ANOVA) للفروق في متوسطات استجابات أفراد العينة حول درجة فاعلية التعلم عن بعد في ظل تفشّي فيروس الكورونا من وجهة نظر طلبة المعاهد العليا في منطقة بئر السبع تعزى مئى

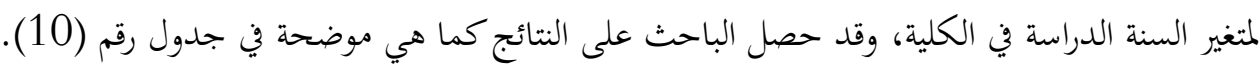
جدول (10): نتائج اختبار تحليل التباين الأحادي للفروق في متوسطات استجابات أفراد العينة حول درجة فاعلية التعلم عن بعد في ظل تفشّي فيروس الكورونا من وجهة نظر طلبة المعاهد العليا في منطقة بئر السبع تعزى لمتغير السنة الدراسة في الكلية

\begin{tabular}{|c|c|c|c|c|c|}
\hline الإحصائية & قيمة ف & متوسط المربعات & درجات الحرية & المجبعات & \\
\hline \multirow{3}{*}{0.128} & \multirow{3}{*}{1.926} & 0.787 & 3 & 2.362 & بين الجموعات \\
\hline & & \multirow{2}{*}{0.409} & 146 & 59.688 & داخل الجموعات \\
\hline & & & 149 & 62.050 & الجموع \\
\hline
\end{tabular}

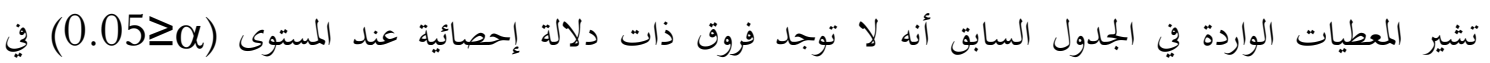
متوسطات استجابات أفراد العينة حول درجة فاعلية التعلم عن بعد في ظل تفشّي فيروس الكورونا من وجهة نظر طلبة المعاهد العليا في منطقة بئر السبع تعزى لمتغير السنة الدراسة في الكلية، وذلك لأن قيمة الدالة الإحصائية المتعلقة بهذا المتغير بلغت (0.128) أي أن هذه القيمة أكبر من قيمة ألفا (0.05)، وبذلك نقبل الفرضية الصفرية. 


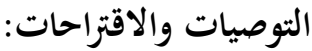

1. أن تعمل المعاهد على اختيار الأنسب من أدوات التكنولوجيا استناداً إلى الإمكانات المتوافرة

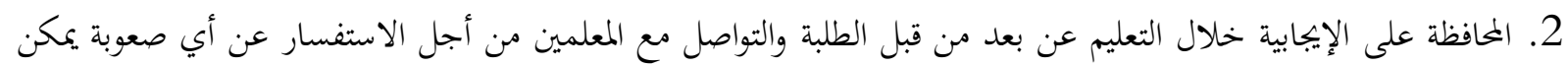
أن تواجه الطلبة 3. علاقة التعليم عن بعد بدافعية الطلبة نخو التعليم. 4. أساليب التقويم من خلال التعليم عن بعد في ظل انتشار جائحة كورونا. 
جريد، أريج، (2020)، معيقات التعليم الالكتروني في فلسطين في ظل أزمة كورونا، ضمن أنشطة مشروع منتدى الشباب للسياسة والتنمية، (أوراق بحثية شبابية)، تنفيذ مؤسسة بال ثينك للدراسات الاستراتيجية.

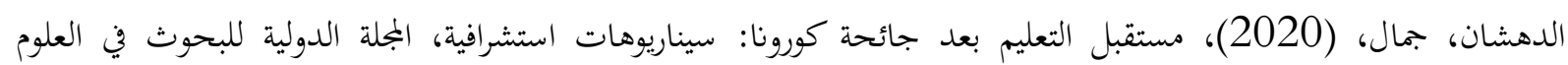

$$
\text { التربوية، المجلد 3، العدد } 4 .
$$

ربابعة، أماني، (2020)، دور التعليم عن بعد في تعزيز التعلم الذاتي لدى طلبة جامعة الزرقاء الخاصة، مجلة جامعة فلسطين للأبحاث والدراسات، العدد 3، الجزء الثاني.

ريم، العتبي، (2020)، التحديات التي واجهت الاسر السعودية في تعليم أبنائها في ظل جائحة كورونا المستجد، المجلة العربية

$$
\text { للنشر العلمي، العدد الثاني والعشرون. }
$$

الشديفات، منيرة، (2020)، واقع توظيف التعليم عن بعد بسبب مرض الكورونا في مداري قصبة المفرق من وجهة نظر مديري

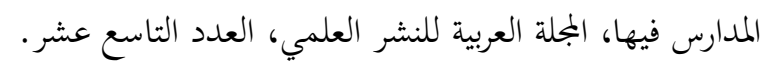

الشرهان، صلاح (2014)، التعليم المفتوح والتعليم عن بعد في الوطن العربي: نهو التطوير والابداع، ورقة مقدمة في المؤتمر الرابع

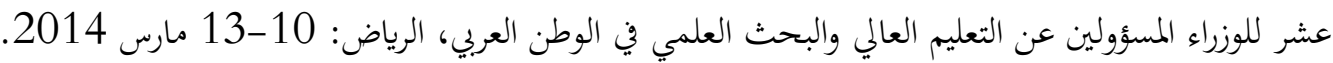

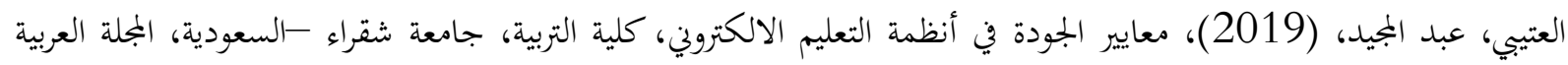

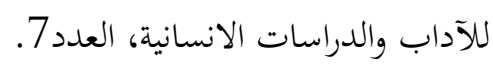

قرعان، محمد، (2021)، مستوى رضا معلمي اللغة العربية في مدينة الزرقاء عن التعليم عن بعد، مجلة افاق العلوم، المجلد 6،

$$
\text { العدد2. }
$$

محمد، زايد، (2020)، أهمية التعليم عن بعد في ظل تفشي فيروس كورونا، المركز الجامعي نور البشير، مجلة الاجتهاد للدراسات

$$
\text { القانونية والاقتصادية، المجلد9، العدد } 4 .
$$

قنبي، عبير وآخرون، (2020): جائحة "كوفيد -19": واقع التعليم الالكتروني في السياق الفلسطيني من وجهة نظر المعلمين، https: //inee.org/system/files/resources/\%3F\%3F\%3F\%3F\%20\%3F\%3.pdf

$$
\text { سناء أحمد فتوح، التعليم عن بعد: نظام تعليمي له مزاياه وعيوبه، منشور على الموقع }
$$

education- https: //www.arageek.com/edu/onl .

$$
\text { موقع منظمة الصحة العالمية. (2019م). فيروس كورونا (كوفيد-19). }
$$

https: //www.who.int/ar/emergencies/diseases/novel-coronavirus-2019

Basilaia، G.، \&Kvavadze، D. (2020). Transition to Online Education in Schools during a SARS-CoV-2 Coronavirus (COVID-19) Pandemic in Georgia. Pedagogical Research، 5 (4)، em0060

Berg، G.، Simonson، M. (2018). Distance learning. Britannica. Retrieve in 2/4/2012 at: https: //www.britannica.com/topic/distance-learning

Draissi، Z. Yong، Q، Z. (2020). COVID-19 Outbreak Response Plan: Implementing Distance Education in Moroccan Universities. School of Education، Shaanxi Normal University، retrieve in 5/4/2020 at: https: //papers.ssrn.com/sol3/papers.cfm?abstract_id=3586783

Yulia، H. (2020). Online Learning to Prevent the Spread of Pandemic Corona Virus in Indonesia. ETERNAL (English Teaching Journal). 11 (1). 